\title{
PENGARUH KEPEMIMPINAN, IKLIM ORGANISASI, DAN KEPUASAN KERJA TERHADAP KINERJA
}

\author{
Ahmad Faisal dan Kartika Dian Lestari \\ Dosen Tetap dan mahasiswa MM Unsurya \\ afaisal@univeristassuryadarma.ac.id
}

\begin{abstract}
This study aims to obtain facts, data and information, valid and true, and can be trusted about the influence of Leadership, Organizational Climate, Job Satisfaction on Teacher Performance, at Raflesia Foundation Depok.

Data derived from questionnaires distributed were analyzed data, among others: description of data, testing of research requirements, including normality test, homogeneity test, and linearity test. To prove the influence of variables of Leadership (X1), Organizational Climate (X2) and Job Satisfaction (X3) on Performance $(Y)$ in this research, used data analysis technique with path analysis.

Based on result of research analysis: 1) There is an influence of Leadership (X1) to Job Satisfaction (X3) 0,601; 2) There is an influence of Organizational Climate (X2) to Job Satisfaction (X3) equal to 0,283; 3) There is influence of Perception About Leadership (X1) to Performance (Y) equal to 0,310; 4) There is an effect of Organizational Climate $(X 2)$ on Performance $(Y)$ of 0.251 ; 5) There is influence of Job Satisfaction (X3) on Performance ( $Y$ ) of 0.366
\end{abstract}

Key Words: Leadership, Organizational Climate, Job Satisfaction and Performance

\section{PENDAHULUAN}

Sumber daya manusia merupakan aset yang paling penting bagi suatu organisasi, dimana pada hakekatnya berfungsi sebagai faktor penggerak bagi setiap kegiatan didalam organisasi. Suatu organisasi dalam melakukan aktivitasnya untuk mencapai tujuan yang diinginkan perlu adanya manajemen yang baik terutama sumber daya manusia. Sumber daya manusia merupakan modal utama dalam merencanakan, mengorganisir, mengarahkan serta menggerakkan faktor-faktor yang ada dalam suatu organisasi. Manajemen sumber daya manusia baik, diharapkan akan mampu menghasilkan kinerja yang optimal bagi organisasi.

Pencapaian tujuan sebuah oganisasi perlu pengelolaan sumber daya manusia secara efektif dan efesien. Manajemen sumber daya manusia tidak hanya memperhatikan kepentingan organiasasi akan tetapi 
juga harus memperhatikan kebutuhan pegawai dan tuntutan masyarakat luas. Disinilah peran manajemen sumber daya manusia diperlukan untuk memadukan kepentingan-kepentingan tersebut yaitu organiasi atau lembaga, persepsi, dan masyarakat luas menuju tercapainya efektivitas, efisiensi dan produktivitas.

Tidak mudah menjadikan sumber daya manusia sebagai sumber keunggulan bersaing organisasi. Maka dalam suatu organisasi diperlukan suatu sistem manajemen kinerja untuk menilai kemampuan dan keahlian karyawannya. Sistem manajemen kinerja pada dasarnya merupakan salah satu faktor kunci dalam fungsi pemeliharaan karyawan diperusahaan guna mengembangkan perusahaan tersebut secara efektif dan efisien. Sebuah organisasi dapat terbentuk karena dipengaruhi oleh beberapa aspek seperti penyatuan visi dan misi serta tujuan yang sama dengan perwujudan eksistensi sekelompok orang tersebut terhadap masyarakat. Organisasi yang dianggap baik adalah organisasi yang dapat diakui keberadaannya oleh masyarakat disekitarnya, karena memberikan kontribusi.

$$
\text { Pentingnya sumber daya }
$$
manusia bagi kelangsungan organisasi telah menjadi pertimbangan setiap organisasi. Bekerja sebenarnya bukan sekadar aktivitas mencari penghasilan saja. Menurut survei yang dilakukan Accenture "Defining Success Your Way" tahun 2013. Survei ini juga mengungkapkan bahwa peningkatan kepuasan akan pekerjaan juga disebabkan oleh lingkungan kerja yang lebih menyenangkan dan kondusif untuk peningkatan kinerja mereka. Melalui survei ini, Accenture juga mengungkapkan lingkungan yang ideal dan paling diinginkan para pekerja untuk meningkatkan kepuasan mereka dalam bekerja. Survei ini melaporkan bahwa 59 persen responden mengaku bahwa lingkungan kerja yang baik dan bisa memberikan kepuasan kerja adalah yang tahu bagaimana cara menghargai karyawannya dalam segala hal. "Adanya pengertian dan penghargaan dari bos atau perusahaan bisa meningkatkan semangat pekerja untuk bisa lebih berprestasi, dan meningkatkan kinerja mereka dengan 
lebih baik," jelasnya. Perusahaan yang bisa mengerti dan menghargai karyawannya akan memiliki hubungan yang lebih erat dengan karyawan.

Yayasan Raflesia Depok merupakan oganisasi yang bergerak dalam bidang pendidikan mempunyai visi dan misi untuk meningkatkan kualitas sumber daya manusia guna ikut memajukan dunia pendidikan, untuk mengetahui seberapa baik kualitas sumber daya manusiannya Yayasan Raflesia Depok setiap tahun membuat penilaian kinerja bagi karyawan terutama bagi para pengajar.

Lembaga Pendidikan Yayasan

Raflesia Depok merupakan salah satu bentuk organisasi yang menjalani fungsi manajemen salah satunya adalah pengawasan). Pengawasan adalah segala usaha atau kegiatan untuk mengetahui kenyataan yang sebenarnya mengenai pelaksanaan tugas atau kegiatan, melihat kesesuaian dengan yang semestinya atau tidak.

Iklim organisasi yang baik terlihat adanya keakraban, kerukunan, saling bantu membantu diantara anggota organisasi. Dalam organisasi pendidikan, jika pegawai dalam bekerja merasa tenang, aman, puas, maka pegawai akan senang sehingga dalam pekerjaan mempunyai dampak positif terhadap kinerja pegawai sendiri. Iklim organisasi yang kurang mendukung, misalnya terbentuknya kelompok-kelompok atau klik yang akan mengganggu kinerja. Dari teoriteori yang berkembang, mengenai iklim organisasi yang kondusif dapat mengembangkan potensi diri pegawai, sehingga mereka akan puas dalam bekerja, lebih-lebih dengan adanya persepsi pegawai tentang kepemimpinan yang baik pada yang akhirnya diharapkan dapat meningkatkan kinerja.

Kepuasan kerja pegawai tidak bisa dilepaskan dari kenyataan bahwa kepuasan kerja pegawai dapat dicapai apabila semua harapannya dapat dipenuhi dalam melaksanakan tugas pekerjaannya. Kepuasan kerja merupakan refleksi dari perasaan dan sikap pegawai terhadap pekerjaannya, yang merupakan interaksi antara yang bersangkutan dengan lingkungan kerjanya. Pegawai dengan kepuasan kerja diharapkan akan mengeluarkan seluruh kemampuan dan energi yang dimiliki untuk menyelesaikan 
pekerjaan, sehingga dapat menghasilkan kinerja yang optimal bagi tujuan sekolah.

\section{PERUMUSAN MASALAH}

Agar pembatasan masalah tersebut lebih operasional dan dapat dibuktikan melalui pembuktian hipotesis penelitian, maka penulis dalam penelitian ini merumuskan sebagai berikut:

1. Apakah terdapat pengaruh kepemimpinan terhadap kepuasan kerja pegawai?

2. Apakah terdapat pengaruh iklim organisasi terhadap kepuasan kerja?

3. Apakah terdapat pengaruh kepemimpinan terhadap kinerja?

4. Apakah terdapat pengaruh iklim organisasi terhadap kinerja?

5. Apakah terdapat pengaruh kepuasan kerja terhadap kinerja?

\section{TINJAUAN TEORI}

Sumber daya manusia merupakan sector sentral dan faktor penting dalam rangka pencapaian tujuan di suatu perusahaan, karena dengan adanya kemampuan skill para pekerja dan kualitas sumber daya manusia dapat menggerakkan perusahaan dengan baik dan benar. Tujuan perusahaan tidak mungkin akan terwujud tanpa peran aktif dari manusia yang mengelola perusahaan. Kemajuan teknologi tidak akan menggeser peran sumber daya manusia secara keseluruhan dalam perusahaan karena ada hal-hal yang tidak dapat di lakukan oleh teknologi karena itu di perlukan kemampuan yang baik dalam manajemen sumber daya manusia agar sumber daya manusia dapat di kelola dengan baik dan efisien.

Manajemen sumber daya manusia adalah kebijakan dan praktik di dalam menggerakan sumber daya manusia atau aspek-aspek terkait. Posisi manajemen di dalam sumber daya manusia yang mencakup kegiatan perekrutan, penyaringan, pelatihan, pemberian penghargaan dan penilaian.

\section{KEPEMIMPINAN}

Sarros dan Butchatsky mengungkapkan bahwa leadership is defined as the purposeful behaviuor of influencing others to contribute to a commonly agreed goal for the benefit of individual as well as the 
organization or common good (kepemimpinan didefinisikan sebagai perilaku bertujuan mempengaruhi orang lain untuk berkontribusi pada tujuan yang disepakati bersama untuk kepentingan individu maupun organisasi atau kebaikan bersama). Dalam organisasi kepemimpinan yang berbeda memang diharapkan, hal ini dimaksudkan agar setiap komponen organisasi yang terlibat dapat menunjukkan kinerja yang maksimal sehingga tercipta produktivitas yang tinggi.

Menurut Griffin dan Moorhead leadership is the use of noncoercieve influence to direct and coordinate the activities of group members to meet a goal (Kepemimpinan adalah penggunaan pengaruh non kognitif untuk mengarahkan dan mengkoordinasikan kegiatan anggota kelompok untuk memenuhi suatu tujuan). Peran seorang pemimpin dibutuhkan untuk mengelola baik mengarahkan maupun mengkoordinasikan setiap kegiatan. Kepemimpinan yang baik mampu membawa angoota kelompoknya mencapai tujuan yang diinginkan.
Menurut Jaffe Leadership is such an open-ended phenomenon that the thousands of studies and guides on the topic, taken together, produce a belwidering and contradictory assemblage of finding and advice (Kepemimpinan adalah sebuah fenomena terbuka bahwa ribuan studi dan panduan mengenai topik ini, digabungkan, menghasilkan kumpulan temuan dan saran yang membingungkan dan kontradiktif). Dalam suatu organisasi kepemimpinan yang berbeda-beda akan membawa dampak yang berbeda bagi suatu organisasi dalam mencapai tujuan.

Berdasarkan uraian di atas dapat disintesiskan bahwa kepemimpinan adalah perilaku dan kemampuan yang melekat pada diri seseorang terdiri dari faktor-faktor intern maupun faktor-faktor ekstern. yang bertujuan mempengaruhi orang lain, mengarahkan dan mengkoordinasikan kegiatan anggota kelompok untuk memenuhi suatu tujuan yang berbeda-beda akan membawa dampak yang berbeda bagi suatu organisasi dalam mencapai tujuan. Untuk melihat kepemimpinan dapat dilihat dengan indikator (1) 
Mengemukakan mutu lulusan, (2)

Pemberitahuan struktur,

Perwakilan, (4) Asumsi peranan, (5)

Persuasi, (6) Orientasi ke atas, (7)

Toleransi kebebasan, (8) Toleransi

ketidakpastian, (9) Konsiderasi/

perhatian, (10) Ketepatan prakiraan, dan (11) Integarasi.

\section{IKLIM ORGANISASI}

Litwin dan Stringer menyatakan bahwa iklim organisasi sebagai a concept describing the subjective nature or quality of the organizational environment. Its properties can be perceived or experienced by members of the organization and reported by them in an appropriate questionare (sebuah konsep yang menggambarkan sifat subjektif atau kualitas lingkungan organisasi. Sifat-sifatnya dapat dirasakan atau dialami oleh anggota organisasi dan dilaporkan oleh mereka dalam sebuah pertanyaan yang sesuai) . Iklim organisasi merupakan suasana di dalam organisasi dimana tiap pelaku organisasi di dalam organisasi saling membantu, saling menilai, dan memahami antara satu dengan yang lain. Iklim organisasi ikut mengambil bagian penting dalam organisasi. Keduanya saling mempengaruhi satu sama lain.

Iklim organisasi merupakan faktor yang dapat mempengaruhi motivasi, prestasi, dan kepuasan kerja para pekerja didalam organisasi, baik posisinya sebagai atasan maupun bawahan. Iklim organisasi akan mempengaruhi hal tersebut dengan memberi harapan terhadap para pekerja akan konsekuensi yang akan timbul dari berbagai keputusan yang diambil. Dalam hal ini para pekerja mengharapkan imbalan dan kepuasan atau bahkan merasa frustrasi atas dasar persepsi mereka terhadap iklim organisasinya. Maka iklim organisasi yang sehat adalah sebuah rencana jangka panjang yang melihat dan mempersepsi iklim organisasi sebagai aset organisasi.

Berdasarkan uraian di atas dapat disintesiskan bahwa Iklim Organisasi adalah konsep sistem organisasi yang dinamis sebagai hasil kombinasi dari struktur formal dan struktur informal dimana tiap pelaku organisasi di dalam organisasi saling membantu, saling menilai, dan memahami antara satu dengan yang 
lain yang dapat mempengaruhi motivasi, prestasi, dan kepuasan kerja para pekerja didalam organisasi, baik posisinya sebagai atasan maupun bawahan. Untuk mencapai iklim organisasi yang baik dapat dilihat dengan indikator (1) struktur, (2) standar-standar, (3) tanggung jawab, (4) penghargaan, (5) dukungan, (6) tantangan, (7) komitmen, (8) imbalan, (9) kejelasan, (10) fleksibel.

\section{KEPUASAN KERJA}

Sondang H. Sianggian mengatakan bahwa kepuasan kerja merupkan suatu cara pandang seseorang baik yang bersifat positif maupun bersifat negatif tentang pekerjaannya . Cara pandang yang bersifat positif akan menimbulkan sikap puas dalam bekerja tetapi cara pandang yang bersifat negatif akan menimbulkan ketidakpuasan.

Moh As'ad mengatakan bahwa kepuasan kerja adalah keadaan emosional yang menyenangkan atau tidak menyenangkan dimana para karyawan memandang pekerjaannya . Keadaan emosional yang menyenangkan ditandai dengan menjalani pekerjaan dengan ringan dan tanpa beban. Tapi sebaliknya keadaan emosional yang tidak menyenangkan membuat karyawan merasa terbebani dengan tugas dan tanggung jawab yang diberikannya. Keadaan emosional karyawan dimana terjadi atau tidak terjadi adalah titik temu antara nilai balas jasa kerja karyawan dari perusahaan atau organisasi dengan tingkat nilai balas jasa yang memang diinginkan untuk karyawan yang bersangkutan.

Robbin menyatakan bahwa kepuasan kerja sebagai suatu sikap umum seorang individu terhadap pekerjaan. Kepuasan kerja akan mendorong karyawan untuk berprestasi lebih baik. Prestasi yang lebih baik akan menimbulkan imbalan ekonomi dan psikologis yang lebih tinggi. Apabila imbalan tersebut dipandang pantas dan adil maka timbul kepuasan yang lebih besar karena karyawan merasa bahwa mereka menerima imbalan sesuai dengan prestasinya. Sebaliknya apabila imbalan dipandang tidak sesuai dengan tingkat prestasi maka cenderung timbul ketidakpastian.

Berdasarkan uraian di atas dapat disintesiskan bahwa kepuasan 
kerja adalah keadaan emosional yang menyenangkan atau tidak menyenangkan dimana para karyawan memandang pekerjaannya sebagai suatu sikap umum seorang individu terhadap pekerjaan yang akan mendorong karyawan untuk berprestasi lebih baik berdasarkan hasil dari sebuah evaluasi karakteristiknya. Pemahaman mengenai kepauasan kerja dapat dilakukan dengan mengetahui dengan indikator: (1) gaji, (2) pekerjaan, (3) promosi, (4) supervisi, (5) rekan kerja, (6) kondisi kerja, (7) kesesuaian kepribadian dengan pekerjaan.

\section{KINERJA}

Armstrong mengatakan bahwa "Performance is often defined simply in output terms - the achievement of quantified objectives. But performance is a matter not only of what people achieve but how they achieve it" (Kinerja sering didefinisikan hanya dalam hal keluaran - pencapaian tujuan diukur. Tapi kinerja adalah masalah tidak hanya dari apa yang orang mencapai tapi bagaimana mereka mencapainya). Kinerja seringkali didefinisikan berdasarkan output, yaitu pencapaian tujuan dalam bentuk angka-angka tertentu. Tapi kinerja tidak hanya mengenai apa yang dicapai tapi bagaimana proses pencapaian tersebut Menurut Hasibuan kinerja adalah suatu hasil kerja yang dicapai oleh seseorang dalam melaksanakan tugas-tugasnya yang dibebankan kepadanya yang didasarkan atas kecakapan, pengalaman dan kesungguhan serta sewaktu-waktu. Kinerja karyawan adalah hasil yang ingin dicapai oleh seseorang didalam melaksanakan tugas pekerjaannya yang mempengaruhi kontribusi yang mereka berikan kepada perusahaan

Mangkunegara mengatakan bahwa kinerja adalah hasil kerja secara kualitas dan kuantitas yang dicapai oleh pegawai dalam melaksanakan tugasnya sesuai dengan tanggung jawab yang diberikan kepadanya. Kinerja menjadi perhatian penting dalam setiap organisasi. Tanpa adanya kinerja, tujuan organisasi tidak akan tercapai.

Bernardin dan Russel menyatakan bahwa kinerja merupakan catatan outcome yang dihasilkan dari fungsi pegawai tertentu atau kegiatan 
yang dilakukan selama periode waktu tertentu . Berkaitan dengan pegawai dalam organisasi merupakan profesi profesional dimana dituntut untuk berupaya semaksimal mungkin dalam menjalankan profesinya. Sebagai seorang profesional maka tugas pegawai hendaknya dapat berimbas kepada tujuan organisasi. Dalam hal ini pegawai hendaknya dapat meningkatkan terus kinerjanya yang merupakan modal bagi keberhasilan oraganisasi itu sendiri.

Berdasarkan uraian di atas dapat disintesiskan bahwa Kinerja adalah ekspresi potensi berupa perilaku atau cara seseorang atau kelompok orang dalam melaksanakan suatu kegiatan atau tugas sehingga menghasilkan suatu produk yang merupakan wujud dari semua tugas dan tanggung jawab pekerjaan yang diberikan kepadanya kemampuan dalam perencanaan program pengajaran, pelaksanaan kegiatan pembelajaran dan evaluasi hasil pembelajaran. Untuk mencapai kinerja yang baik dapat dilihat dengan indikator (1) Kualitas kerja, (2) Kuantitas kerja, (3) tepat waktu, (3) Efektivitas biaya, (4) Kebutuhan supervisi, (5) Pengaruh perseorangan, (6) Keandalan, (7) Kehadiran, (8) Kemampuan bekerja sama.

\section{KERANGKA BERPIKIR}

Dari masalah dan didukung oleh kajian teori dari hasil penelitian terdahulu, maka disusunlah kerangka pemikiran. Kerangka berpikir dalam penelitian ini adalah mengungkap dan mengkaji informasi empirik tentang pengaruh langsung dan tidak langsung variabel: Kepemimpinan $\left(\mathrm{X}_{1}\right)$, Iklim Organisasi $\left(\mathrm{X}_{2}\right)$, Kepuasan Kerja $\left(\mathrm{X}_{3}\right)$ dan Kinerja (Y). Pengaruh antar variabel dapat diuraikan sebagai berikut:

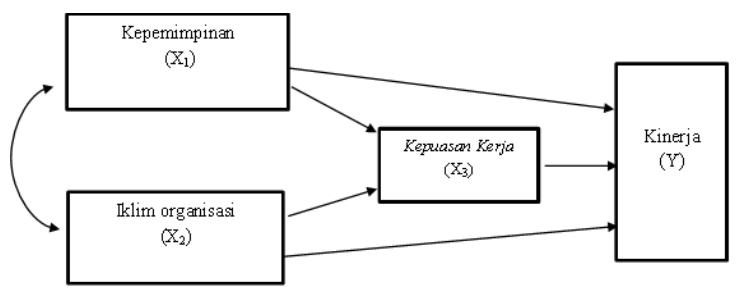

Gambar Kerangka Berpikir

Keterangan:

$\mathrm{X}_{1}$ : Persepsi Tentang Kepemimpina

$\mathrm{X}_{3}$ : Kepuasan Kerja

$\mathrm{X}_{2}$ : Iklim organisasi

Y : Kinerja 


\section{PEMBAHASAN}

Sebelum dilakukan perhitungan untuk menguji model dengan menggunakan metode analisis jalur, maka diperlukan data hasil penelitian yang telah di uji dan memenuhi seluruh persyaratan. analisis jalur yang digunakan dalam pengujian model ini adalah analisis jalur model trimming. Model trimming adalah model yang digunakan untuk memperbaiki suatu model struktur jalur analisis dengan cara mengeluarakan dari model variabel yang koefisien jalur diuji secara keseluruhan ternyata ada variabel yang tidak signifikan. Adapun cara menggunakan model trimming tersebut adalah dengan menghitung ulang koefisien jalur tanpa menyertakan variabel eksogen yang koefisien jalurnya tidak signifikan.

\begin{tabular}{|c|c|c|c|c|c|c|}
\hline \multicolumn{7}{|c|}{ Coefficients $^{a}$} \\
\hline \multirow[b]{3}{*}{ Model } & & \multirow{2}{*}{\multicolumn{2}{|c|}{ Unstandardized Coefficients }} & \multirow{3}{*}{$\begin{array}{l}\text { Standardized } \\
\text { Coefficients } \\
\text { Beta }\end{array}$} & \multirow[b]{3}{*}{$\mathrm{t}$} & \multirow[b]{3}{*}{ Sig. } \\
\hline & & & & & & \\
\hline & & B & Std. Error & & & \\
\hline \multirow[t]{3}{*}{1} & (Constant) & -1.676 & 7.530 & & -.223 & .824 \\
\hline & KEPEMIMPINAN & .669 & .111 & .601 & 6.012 & .000 \\
\hline & $\begin{array}{l}\text { IKLIM } \\
\text { ORGANISASI }\end{array}$ & .345 & .122 & .283 & 2.835 & .006 \\
\hline
\end{tabular}

a. Dependent Variable: KEPUASAN KERJA

Model 1 : Summary $X_{1}$, dan $X_{2}$ terhadap $X_{3}$

\begin{tabular}{l|l|l|l}
\multicolumn{2}{l}{$\begin{array}{l}\text { Model Summary } \\
\text { Model }\end{array}$} & & \\
\hline 1 & R Square & Adjusted R Square & $\begin{array}{l}\text { Std. Error of the } \\
\text { Estimate }\end{array}$ \\
\hline $1 \quad .846^{\mathrm{a}}$ & .716 & .709 & 7.08857 \\
\hline a. Predictors: (Constant), IKLIM ORGANISASI, KEPEMIMPINAN
\end{tabular}

Model 1 : Anova $\mathrm{X}_{1}$, dan $\mathrm{X}_{2}$ terhadap $\mathrm{X}_{3}$

Dari tabel dapat dilihat $\quad X_{3}$ atau $\rho_{32}=0,283$ maka persamaan bahwa koefisien jalur $X_{1}$, ke $X_{2}$ atau jalur pada $\mathrm{Sub}$ - struktur 1 adalah $\mathrm{X}_{3}$ $\rho_{31}=0,601$ dan koefisien jalur $\mathrm{X}_{2}$ ke $\quad=0,601 \mathrm{X}_{1}+0,283 \mathrm{X}_{2}+\varepsilon_{1}$. 
Tabel menunjukkan nilai $\mathrm{R}^{2} \mathrm{x}_{3}\left(\mathrm{x}_{1}, \mathrm{x}_{2}\right)$ $=0,846$. sehingga koefisien residu dapat dihitung dengan menggunakan rumus

$$
3 \varepsilon=\sqrt{1-R_{X_{3}\left(X_{1} X_{2}\right)}^{2}}=
$$

0,392 sehingga koefisien

residu $\rho \mathrm{X}_{3} \varepsilon=\sqrt{1-0,848}=$

0,392. Setelah koefisien jalur diketahui , maka persamaan jalur pada sub - struktur 1 menjadi $X_{3}=0,601$

$X_{1}+0,283 X_{2}+0,392$

Pengujian keberartian koefisien jalur secara parsial pada Sub - Struktur 1 dapat dilakukam dengan melihat tabel. Dari hasil perhitungan diperoleh data yang dapat dilihat pada tabel sebagai berikut:

Tabel

Hasil Pengujian Keberatian Koefisien Jalur Sub-Struktur 1

\begin{tabular}{|c|l|l|l|l|}
\hline Jalur & $\begin{array}{l}\text { Koefisien } \\
\text { Jalur }\end{array}$ & $\mathbf{t}_{\text {hitung }}$ & $\mathbf{t}_{\text {tabel }}$ & Hasil Uji \\
\hline$\rho_{31}$ & 0,601 & 6,012 & 1,988 & Signifikan \\
\hline$\rho_{32}$ & 0,283 & 2,835 & 1,988 & Signifikan \\
\hline
\end{tabular}

Dari tabel diketahui bahwa nilai hitung Sig. lebih kecil dari pada tingkat $\alpha$ yang digunakan (yaitu 0.05) atau $0.000<0.05$ dan nilai $F_{\text {hitung }}$ $(103,512)>$ Ftabel $(3,108)$. sehingga $\mathrm{H}_{0}$ ditolak , artinya terdapat pengaruh yang berarti atau signifikan antara Kepemimpinan $\left(\mathrm{X}_{1}\right)$ dan Iklim Organisasi $\left(\mathrm{X}_{2}\right)$ terhadap Kepuasan $\operatorname{Kerja}\left(\mathrm{X}_{3}\right)$.

\section{Perhitungan Besar Pengaruh pada}

\section{Sub - Struktur 1}

Untuk mengetahui besarnya pengaruh yang diterima oleh sebuah Variabel endogen dari dua buah variabel endogen. dapat secara parsial (langsung maupun tidak langsung melalui varibel eksogen lain ) maupun secara bersama - sama

a. menghitung pengaruh langsung pengaruh tidak langsung serta pengaruh total variabel Kepemimpinan $\left(\mathrm{X}_{1}\right)$, terhadap variabel Iklim Organisasi $\left(\mathrm{X}_{2}\right)$ secara parsial, sebagai berikut:

1) besarnya pengaruh langsung variabel $\mathrm{X}_{1}$ terhadap variabel $\mathrm{X}_{3}$ $(0,601)^{2}=0,361$

2) besarnya pengaruh tidak langsung variabel $\mathrm{X}_{1}$ terhadap variabel $\mathrm{X}_{3}$ melalui $\mathrm{X}_{2}$ 
$0,601 \times 0,808 \times 0,283=0,137$

3) besarnya pengaruh total variabel

$\mathrm{X}_{1}$ terhadap variabel $\mathrm{X}_{3}$

$0,361+0,137=0,498$

Kesimpulannya pengaruh

variabel Kepemimpinan $\left(\mathrm{X}_{1}\right)$

terhadap variabel Kepuasan Kerja $\left(\mathrm{X}_{3}\right)$ adalah sebesar 0,498 hal ini berarti Kepuasan Kerja Kerja ditentukan oleh Kepemimpinan sebesar $49.8 \%$

b. Menghitung pengaruh langsung pengaruh tidak langsung serta pengaruh total variabel Iklim Organisasi $\left(\mathrm{X}_{2}\right)$ terhadap variabel Kepuasan Kerja Kerja $\left(\mathrm{X}_{3}\right)$ secara parsial, sebagai berikut:

1) besarnya pengaruh langsung variabel $\mathrm{X}_{1}$ terhadap variabel $\mathrm{X}_{3}$
$(0,283)^{2}=0,080$

2) besarnya pengaruh tidak langsung variabel $\mathrm{X}_{1}$ terhadap variabel $\mathrm{X}_{3}$ melalui $\mathrm{X}_{2}$ $0,283 \times 0,808 \times 0,601=0,137$

3) besarnya pengaruh total variabel $\mathrm{X}_{1}$ terhadap variabel $\mathrm{X}_{3}$ $0,080+0,137=0,217$.

Kesimpulannya pengaruh variabel Iklim Organisasi $\left(\mathrm{X}_{2}\right)$ terhadap variabel Kepuasan Kerja $\left(\mathrm{X}_{3}\right)$ adalah sebesar 0,217 hal ini berarti Kepuasan Kerja kerja ditentukan oleh Iklim Organisasi sebesar $21.7 \%$.

\begin{tabular}{|c|c|c|c|c|c|c|}
\hline \multicolumn{7}{|c|}{ Coefficients $^{\mathrm{a}}$} \\
\hline & & \multicolumn{2}{|c|}{ Unstandardized Coefficients } & \multirow{2}{*}{$\begin{array}{l}\text { Standardized } \\
\text { Coefficients } \\
\text { Beta } \\
\end{array}$} & \multirow[b]{2}{*}{$\mathrm{t}$} & \multirow[b]{2}{*}{ Sig. } \\
\hline \multicolumn{2}{|c|}{ Model } & $\mathrm{B}$ & Std. Error & & & \\
\hline \multirow[t]{4}{*}{1} & (Constant) & -2.148 & 7.240 & & -.297 & .767 \\
\hline & KEPEMIMPINAN & .351 & .128 & .310 & 2.730 & .008 \\
\hline & IKLIM ORGANISASI & .311 & .123 & .251 & 2.538 & .013 \\
\hline & KEPUASAN KERJA & .372 & .106 & .366 & 3.508 & .001 \\
\hline
\end{tabular}

a. Dependent Variable: KINERJA 
Coefficients $^{\mathrm{a}}$

\begin{tabular}{|c|c|c|c|c|c|c|}
\hline \multirow[b]{2}{*}{ Model } & & \multicolumn{2}{|c|}{ Unstandardized Coefficients } & \multirow{2}{*}{$\begin{array}{l}\text { Standardized } \\
\text { Coefficients } \\
\text { Beta }\end{array}$} & \multirow[b]{2}{*}{$\mathrm{t}$} & \multirow[b]{2}{*}{ Sig. } \\
\hline & & $\mathrm{B}$ & Std. Error & & & \\
\hline \multirow[t]{4}{*}{1} & (Constant) & -2.148 & 7.240 & & -.297 & .767 \\
\hline & KEPEMIMPINAN & .351 & .128 & .310 & 2.730 & .008 \\
\hline & IKLIM ORGANISASI & .311 & .123 & .251 & 2.538 & .013 \\
\hline & KEPUASAN KERJA & .372 & .106 & .366 & 3.508 & .001 \\
\hline
\end{tabular}

a. Dependent Variable: KINERJA

Perhitungan Besar Pengaruh pada Sub - Struktur 2

Untuk mengetahui besarnya pengaruh yang diterima oleh sebuah Variabel endogen dari dua buah variabel endogen. dapat secara parsial (langsung maupun tidak langsung melalui varibel eksogen lain ) maupun secara bersama - sama

a. menghitung pengaruh langsung pengaruh tidak langsung serta pengaruh total variabel Kepemimpinan $\left(\mathrm{X}_{1}\right)$, terhadap variabel Kinerja (Y) secara parsial , sebagai berikut:

1) besarnya pengaruh langsung variabel $\mathrm{X}_{1}$ terhadap variabel Y

$(0,310)^{2}=0,096$

2) besarnya pengaruh tidak langsung variabel $\mathrm{X}_{1}$ terhadap variabel $\mathrm{Y}$ melalui $\mathrm{X}_{2}$

$0,310 \times 0,808 \times 0,251=0,063$
3) besarnya pengaruh tidak langsung variabel $\mathrm{X}_{1}$ terhadap variabel $\mathrm{Y}$ melalui $\mathrm{X}_{3}$

$0,310 \times 0,830 \times 0,366=0,092$

4) besarnya pengaruh total variabel $\mathrm{X}_{1}$ terhadap variabel $\mathrm{X}_{3}$

$0,096+0,063+0,092=0,251$

Kesimpulannya pengaruh variabel Kepemimpinan $\left(\mathrm{X}_{1}\right)$ terhadap variabel Kinerja (Y) adalah sebesar 0,251 hal ini berarti Kinerja ditentukan oleh Kepemimpinan sebesar $25.1 \%$

b. Menghitung pengaruh langsung pengaruh tidak langsung serta pengaruh total variabel Iklim Organisasi $\left(\mathrm{X}_{2}\right)$ terhadap variabel Kinerja (Y) secara parsial, sebagai berikut:

1) besarnya pengaruh langsung variabel $\mathrm{X}_{2}$ terhadap variabel $\mathrm{Y}$ $(0,251)^{2}=0,053$ 
2) besarnya pengaruh tidak langsung variabel $\mathrm{X}_{2}$ terhadap variabel $\mathrm{Y}$ melalui $\mathrm{X}_{1}$

$0,251 \times 0,808 \times 0,310=0,063$

3) besarnya pengaruh tidak langsung variabel $\mathrm{X}_{2}$ terhadap variabel $\mathrm{Y}$ melalui $\mathrm{X}_{3}$

$0,251 \times 0,769 \times 0,366=0,071$

4) besarnya pengaruh total variabel $\mathrm{X}_{1}$ terhadap variabel $\mathrm{X}_{3}$ $0,053+0,063+0,071=0,187$

Kesimpulannya pengaruh variabel Iklim Organisasi $\left(\mathrm{X}_{2}\right)$ terhadap variabel Kinerja (Y) adalah sebesar 0,187 hal ini berarti Kinerja ditentukan oleh Iklim Organisasi sebesar $18.7 \%$

c. Menghitung pengaruh langsung pengaruh tidak langsung serta pengaruh total variabel Kepuasan Kerja $\left(\mathrm{X}_{3}\right)$ terhadap variabel Kinerja (Y) secara parsial, sebagai berikut:

1) besarnya pengaruh langsung variabel $\mathrm{X}_{3}$ terhadap variabel $\mathrm{Y}$

$$
(0,366)^{2}=0,134
$$

2) besarnya pengaruh tidak langsung variabel $\mathrm{X}_{3}$ terhadap variabel $\mathrm{Y}$ melalui $\mathrm{X}_{1}$ $0,366 \times 0,830 \times 0,310=0,092$
3) besarnya pengaruh tidak langsung variabel $\mathrm{X}_{2}$ terhadap variabel $\mathrm{Y}$ melalui $\mathrm{X}_{3}$

$0,366 \times 0,769 \times 0,251=0,071$

4) besarnya pengaruh total variabel $\mathrm{X}_{3}$ terhadap variabel $\mathrm{Y}$

$0,134+0,092+0,071=0,297$

Kesimpulannya pengaruh variabel Kepuasan Kerja $\left(\mathrm{X}_{3}\right)$ terhadap variabel Kinerja (Y) adalah sebesar 0,297 hal ini berarti Kinerja ditentukan oleh Kepuasan Kerja sebesar $29.7 \%$

\section{KESIMPULAN}

Berdasarkan hasil analisis data dan pembahasan hasil penelitian, maka temuan penelitian dapat disimpulkan sebagai berikut:

1. Terdapat pengaruh Langsung Kepemimpinan terhadap Kepuasan Kerja Guru di Yayasan Raflesia Depok. Temuan ini dapat di artikan bahwa tinggi rendahnya Kepuasan Kerja salah satu faktornya dipengaruhi oleh Persepsi Tentang Kepemimpinan, sehingga jika Persepsi Tentang Kepemimpinan ditingkatkan, dapat meningkatakan Kepuasan Kerja. 
2. Terdapat pengaruh Langsung Iklim Organisasi terhadap Kepuasan Kerja Guru di Yayasan Raflesia Depok. Temuan ini dapat di artikan bahwa tinggi rendahnya Kepuasan Kerja salah satu faktornya dipengaruhi oleh Iklim Organisasi, sehingga jika Persepsi Tentang Kepemimpinan ditingkatkan, dapat meningkatakan Kepuasan Kerja.

3. Terdapat pengaruh Langsung Persepsi Tentang Kepemimpinan terhadap Kinerja Guru di Yayasan Raflesia Depok. Temuan ini dapat di artikan bahwa tinggi rendahnya Kinerja salah satu faktornya dipengaruhi oleh Persepsi Tentang Kepemimpinan, sehingga jika Persepsi Tentang Kepemimpinan ditingkatkan, dapat meningkatakan Kinerja.

4. Terdapat pengaruh Langsung Iklim Organisasi terhadap Kinerja Guru di Yayasan Raflesia Depok. Temuan ini dapat di artikan bahwa tinggi rendahnya Kinerja salah satu faktornya dipengaruhi oleh Iklim Organisasi, sehingga jika Iklim Organisasi

ditingkatkan, dapat meningkatakan Kinerja

5. Terdapat pengaruh Langsung Kepuasan Kerja terhadap Kinerja Guru di Yayasan Raflesia Depok. Temuan ini dapat di artikan bahwa tinggi rendahnya Kinerja salah satu faktornya dipengaruhi oleh Kepuasan Kerja, sehingga jika Kepuasasn Kerja ditingkatkan, dapat meningkatakan Kinerja.

\section{DAFTAR PUSTAKA}

Afif, Faisal, "Iklim Organisasi", Http://Sbm.Binus.Ac.Id/Files/ 2013/04/Iklim-

Organisasi.Pdf. tanggal 13 April 2017)

(Diakses

http://www.fe.unpad.ac.id/id/ arsip-fakultas-ekonomiunpad/opini/2130-iklimorganisasi. (Diakses 20 April 2017)

Ambar T, Sulistiyani, dan Rosidah. Manajemen Sumber Daya Manusia. Graha Ilmu: Yogyakarta, 2003.

Armstrong, Michael. Performane Management. London : Kogan-Page, 2006.

Badeni. Kepemimpinan dan Perilaku Organisasi. Bandung: Alfabeta. 2013. 
Bernardin dan Russel. Pintar Manajer, Aneka Pandangan

Kontemporer. Jakarta: Penerbit Binarupa Aksara, 2006.

Blanchard, Ken dan Garry Ridge. Helping People Win at work. Jakarta: PT Elex Media Komputindo, 2010.

Colquitt, Jason A, Jeffery A. Lepine dan Michael Wesson.Organizational Behaviour, Edition II..New York McGraw-Hill, 2011.

Desy Arisandy, "Hubungan Antara Persepsi Karyawan Terhadap Disiplin Kerja Karyawan Bagian Produksi Pabrik Keramik "Ken Lila Production" Di Jakarta, 2004".

http://fahrudin.weebly.com/u ploads/1/3/9/6/13969720/hub ungan_persepsi_karyawan_de ngan_disiplin_karyawan.pdf (diakses tanggal 17 Maret $\underline{2017)}$

Golden, Bernard. Unlock Your Creative Genius. Jakarta: Daras Book, 2013

Griffin dan Moorhead. Organizational Behavior. USA: SouthWestern Cengge Leraning, 2014.

Hasibuan, Malayu SP. Organisasi dan Motivasi Dasar Peningkatan Produktivitas. Jakarta: Bumi Aksara, 2001.
Jackson, Robert L. Mathis dan Jhon. Manajemen Sumber Daya Manusia. Jakarta: Salemba Empat, 2001.

Jaffe, David. Organization Theory : Tension and change. New York: The McGraw Hil Co,panies, 2001.

Joseph H, De Vito.The Interpersonal Communication Book. New York: Person, 2002.

Mangkunegara, A.A. Anwar Prabu. Manajemen Sumber Daya Manusia Perusahaan. Bandung: PT Remaja Rosdakarya, 2001.

Mulyana, Dedy. Ilmu Komunikasi Suatu Pengantar. Bandung: PT Remaja Rosdakarya, 2005.

Noe, Raymon A. Human Resources Management: Gaining A Competitive Advantage. New York: Mc. Graw Hill, 2003.

Priansa, Donni Joni. Perancangan dan Pengembangan SDM. Jakarta: Afabeta, 2016.

Purwanto, Ngalim. Administrasi dan Supervisi Pendidikan. Jakarta: PT Remaja Rosdakarya, 2008.

Raymon, A Noe, Et al. Manajemen Sumber Daya Manusia Mencapai Keunggulan Bersaing. Jakarta : Salemba empat, 2011. 
Rivai, Veithzal. Manajemen Sumber Daya Manusia Untuk Perusahaan Dari Teori ke Praktik. (Jakarta: Raja Grafindo Persada, 2009). P. 54.

Robbin, Stephen P dan Timothy A Judge. Perilaku Organisasi. Jakarta: Salemba empat, 2008.

Robbin, Stephen P. Organizational behavior. New jersey: Pretice Hall, 2001.

Roen, Ferry. "Iklim Organisasi (Organization Climate)". http://perilakuorganisasi.com/ iklim-organisasiorganization-climate.html (Diakses 17 April 2017)

Sedarmayanti, Manajemen Sumber Daya Manusia Reformasi Borokrasi Dan Manajemen Pegawai Negeri Sipil. Bandung: Refika Aditama, 2015.

Siagian, Sondang. Manajemen Sumber Daya Manusia. Jakarta: Bumi Akasara, 2015.

Sabine, Sonnentag (ed), Psychological Management of Individual Performance. West Sussex: John Wiley \& Sons, Ltd.,2002.

Stringer. Leadership and Organizational Leadershih. Upper Siddle River. New Jersey: Prentice Hall, 2002.
Sunyoto, Danang. Penelitian Sumber Daya Manusia. Jakarta: PT Buku Seru, 2015.

Toha, Mifta. Perilaku Organisasi konsep dasar dan aplikasinya. Jakarta, PT Rajagrafindo persada, 2008.

Uno, Hamzah B. Teori Motivasi dan Pengukuranya. Jakarta: Bumi Aksara, 2011.

Wardiah, Mia Lasmi. Teori Perilaku dan Budaya Organisasi. Bandung: Pustaka Setia, 2016.

Wardiah, Mia Lasmi. Teori Perilaku dan budaya organisasi. Jakarta: CV Pustaska Setia, 2016

Wibowo. Perilaku Dalam Organisasi, Jakarta: PT Raja Grafindo Persada, 2014

Winardi. Kepemimpinan dalam Manajemen. Yogyakarta: STIE Yogyakarta. 2000

---------. Manajemen Prilaku Organisasi. Jakarta: Media Group, 2009.

Wirawan. Budaya dan Iklim Organisasi: Teori, Aplikasi dan Penelitian. Jakarta : Salamba Empat, 2007. 